\title{
PENERAPAN APLIKASI PERHIMPUNAN SIMPAN PINJAM MANDIRI PAROKI PADREPIO MEDAN
}

\author{
${ }^{1}$ Megaria Purba* ${ }^{2}$ Marice Saragih*, ${ }^{3}$ Veronika Saragih \\ ${ }^{1,2}$ Manajemen Informatika, AMIK WIDYALOKA Medan ${ }^{3}$ Akademi Maritim Belawan \\ ${ }^{1}$ Jl.Gereja Zaitun No 29 DSN IV Tg.Gusta Kecamatan Sunggal Kabupaten Deli Serdang Propinsi \\ Sumatera Utara Indonesia* megariapurba18@ gmail.com ${ }^{2} \mathrm{Jl}$.Garu IIb Medan \\ Indonesia*maricesaragih@gmail.com ${ }^{3}$ Jl.Aster 1 No 41 Perumnas Helvetia Medan Indonesia* \\ veronicasrgh@gmail.com
}

Received: 2021-02-20, Revised: 2021-03-25, Accepted: 2021-03-28

\begin{abstract}
Abstrak
Koperasi Perhimpunan Simpan Pinjam Mandiri Paroki Padrepio Medan beralamat di Jalan Beringin III No 9 Helvetia Medan meliputi wilayah Gereja Katolik Paroki Padre Pio Helvetia Medan Keuskupan Agung Medan. Koperasi Perhimpunan Simpan Pinjam Mandiri Paroki Padrepio adalah salah satu wadah untuk menggalang kekuatan ekonomi rakyat yang perlu didorong dan ditumbuh kembangkan. Koperasi Perhimpunan Simpan Pinjam Mandiri Paroki Padrepio memiliki Anggaran Dasar dan Anggaran Rumah Tangga didalamnya terdapat aturan, kewajiban dan hak setiap anggota. Dengan semangat keinginan untuk menabung diantara para anggota Koperasi Perhimpunan Simpan Pinjam Mandiri Paroki Padrepio Medan menciptakan modal bersama lalu akan dipinjamkan bagi anggota untuk tujuan kesejahteraan yang diatur sesuai dengan anggaran rumah tangga. Sistem yang digunakan oleh Koperasi Perhimpunan Simpan Pinjam Mandiri Paroki Padrepio masih menggunakan sistem yang manual dengan pengertian bahwa perhitungan transaksi yang disetor oleh para kolektor kepada bendahara masih menggunakan kalkulator dengan perhitungan berulang kali untuk menghindari terjadinya kesalahan sehingga membutuhkan waktu yang lama.Pemberkasan dan buku anggota yang terdiri dari 213 orang menggunakan pencatatan dalam buku besar folio dan kertas file sehingga untuk mencari data dari setiap anggota membutuhkan waktu yang lama dan sering tidak ditemukan karena bisa tercecer atau alasan lain. Koperasi Perhimpunan Simpan Pinjam Mandiri Paroki Padrepio perlu melakukan pengembangan sistem yang sedang berjalan yaitu manual menjadi sistem penerapan aplikasi komputer.untuk pengolahan data yang cepat dan akurat. Aplikasi yang diterapkan adalah Aplikasi Koperasi Perhimpunan Simpan Pinjam Mandiri Paroki Padrepio yaitu hasil penelitian Megaria Purba tahun 2020 . Penerapan Aplikasi Koperasi Perhimpunan Simpan Pinjam Mandiri Paroki Padrepio dengan melalui pendampingan dan pelatihan para pengguna diantaranya adalah para kolektor,bendahara serta admin yang sekaligus menjadi mitra pengabdian AMIK WIDYALOKA. Pendampingan dan pelatihan dilakukan secara tatap muka dilokasi Koperasi Perhimpunan Simpan Pinjam Mandiri Paroki Padrepio jalan Beringin III No 9 Helvetia Medan dengan menggunakan protokol kesehatan karena suasana covid 19.
\end{abstract}

Kata kunci: Penerapan,Aplikasi,Koperasi,Simpan,Pinjam.

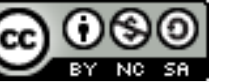




\section{PENDAHULUAN}

\subsection{Latar Belakang}

Koperasi Perhimpunan Simpan Pinjam Mandiri Paroki Padrepio Medan yang menjadi mitra pengabdian AMIK WIDYALOKA masih menggunakan sistem manual artinya perhitungan dan transaksi adalah menggunakan bantuan kokulator serta pemberkasan masih pencatatan dibuku besar folio sehingga membutuhkan waktu yang lama dan kurang akurat. Koperasi Perhimpunan Simpan Pinjam Mandiri Paroki Padrepio adalah salah satu wadah untuk menggalang kekuatan ekonomi rakyat yang perlu didorong dan ditumbuh kembangkan untuk kesejahteraan anggotanya. Sistim manual yang digunakan akan dikembangkan menjadi pebnerapan Aplikasi Koperasi Perhimpunan Simpan Pinjam Mandiri Paroki Padrepio Medan yang sudah dibangun dari hasil penelitian megaria Purba. Penerapan aplikasi akan diterapkan melalui pelatihan dan pendampingan mitra yang terlibat dalam transaksi penyetoran dan penerimaan uang anggota, diantaranya bendahara/admin serta para kolektor.

Para anggota mitra yang akan dilatih dan didampingi memiliki latar belakang pendidikan minimal tamatan sekolah menegah tingkat atas sehingga berdasaran sumber daya manusianya layak untuk dilatih penerapan Aplikasi Koperasi Perhimpunan Simpan Pinjam Mandiri Paroki Padrepio Medan. Pendampingan dan pelatihan akan dilakukan secara tatap muka dilokasi Koperasi Perhimpunan Simpan Pinjam Mandiri Paroki Padrepio Jalan Beringin III No 9 Helvetia Medan dengan mengikuti penggunaan peraturan protokol kesehatan karena masih dalam suasana pandemi covid 19. Berdasarkan observasi dilapangan maka yang menjadi pokok persoalan adalah

1. Bagaimana pengembangan sistem manual Koperasi Perhimpunan Simpan Pinjam Mandiri Paroki Padrepio Medan menjadi sistem penerapan aplikasi komputer

2. Bagaimana menerapkan Aplikasi Koperasi Perhimpunan Simpan Pinjam Mandiri Paroki Padrepio Medan'.

Tujuan dari penerapan Aplikasi Koperasi Perhimpunan Simpan Pinjam Mandiri Paroki Padrepio Medan adalah

1. Untuk mengembangakan sitem manual menjadi sistem penerapan Aplikasi Koperasi Perhimpunan Simpan Pinjam Mandiri Paroki Padrepio

2. Untuk menerapkan Aplikasi Koperasi Perhimpunan Simpan Pinjam Mandiri Paroki Padrepio Medan .

Adapun manfaat pengabdian ini adalah

1. Membantu Koperasi Perhimpunan Simpan Pinjam Mandiri Paroki Padrepio Medan dalam pengolahan data dan informasi yang lebih cepat dan akurat.

2. Menambah Keterampilan para kolektor,bendahara serta admin Koperasi Perhimpunan Simpan Pinjam Mandiri Paroki Padrepio Medan

\section{TINJAUAN LITERATUR}

Penerapan Aplikasi Koperasi Perhimpunan Simpan Pinjam Mandiri Paroki Padrepio dapat dilakukan dengan memahami beberapa hal teori diantaranya adalah sebagai berikut.

Pengertian Komputer merupakan istilah yang umum yang sudah diketahui dan digunakan sehari hari dalam berbagai kalangan . Febrian (2007:108), "Komputer adalah perangkat elektronik yang dapat dipakai untuk mengolah data dengan perantaraan sekumpulan program dan mampu memberikan informasi dari hasil pengolahan tersebut".

Sutabri (2005:106), " komputer adalah sebuah alat elektronik yang dapat menerima data input, mengolah data, dan memberikan informasi dari hasil pengolahan data tersebut dengan menggunakan suatu program yang tersimpan di memori komputer dan dapat menyimpan program dan hasil pengolahannya serta bekerja secara otomatis". 
Pengertian Koperasi; Istilah koperasi perlu dipahami dipengbdian ini karena wadah yang akan di kembangkan adalah bentuk koperasi. Sinaga (2008:V), "dalam ilmu manajemen, sudah sering dihembuskan bahwa "koperasi" merupakan salah satu tipe "organisasi modern" yang di dalamnya terdapat unsur-unsur organisasi yang telah terstruktur di dalam koperasi dan tunduk pada prinsip-prinsip manajemen dalam menjalankan fungsinya".

Wijayanta dan Widyaningsih (2007:82) menyatakan bahwa "koperasi adalah kumpulan individu yang menyelenggarakan kegiatan usaha bertujuan menyejahterakan para anggotanya". Adapun menurut undang-undang No. 25 tahun 1992, koperasi adalah badan usaha yang beranggotakan orang seorang atau badan hukum koperasi dengan melandaskan kegiatannya berdasarkan prinsip koperasi sekaligus sebagai gerakan ekonomi rakyat yang berdasarkan asas kekeluargaan.

Pengertian Simpan Pinjam Menurut Kamus Besar Bahasa Indonesia (1997:986), "simpan adalah menaruh ditempat yang aman agar tidak rusak, hilang dan sebagainya", sedangkan "pinjam adalah memakai barang orang lain untuk sementara waktu".

Surayin (2010:229) menyatakan "simpan pinjam adalah koperasi yang khusus menggalakkan anggotanya untuk menabung, disamping dapat memberikan pinjaman kepada anggotanya".Secara umum usaha simpan pinjam adalah menyediakan uang atau barang atas dasar persetujuan dan perjanjian kedua belah pihak untuk meminjam dalam jangka waktu dan bunga yang telah ditentukan.

Pengertian Data; Pada pengabdian ini jenis koperasi yang akan dibahas adalah koperasi simpan pinjam. Aedi, Nur (2010:129), "data adalah fakta atau bagian dari fakta yang mengandung arti, yang dihubungkan dengan kenyataan, symbol-simbol, gambar-gambar, kata-kata, huruf-huruf, atau symbol yang menunjukkan suatu ide, objek, kondisi atau situasi

Pengertian Pengolahan Data Menurut Longkutoy (1989:4), "pengolahan data adalah segala macam pengolahan terhadap data atau kombinasi-kombinasi dari bermacam-macam pengolahan terhadap data untuk membuat data itu berguna sesuai dengan hasil yang diinginkan, sehingga dapat segera dipakai".

Menurut Slamet B. noor (1990:105) "pengolahan data adalah operasi yang dilakukan oleh mesin otomatis, terhadap data dengan maksud untuk mendapatkan informasi menurut ketentuan yang ada".

Menurut Andri Kristanto (2003:8), "pengolahan data adalah waktu yang digunakan untuk menggambarkan perubahan bentuk data menjadi informasi yang memiliki kegunaan".

Sudarmo (2006:105) mengatakan "pengolahan data adalah operasi yang dilakukan terhadap data untuk memperoleh hasil yang diharapkan" Dalam hal pengolahan data, kristanto (2008:8) menyatakan sebagai berikut: "pengolahan data adalah waktu yang digunakan untuk menggambarkan perubahan bentuk data menjadi informasi yang memiliki kegunaan". Siklus pengolahan data yang baik manual maupun komputerisasi mengalami siklus pengolahan data yang terdiri dari tiga tahap, seperti gambar 2.1

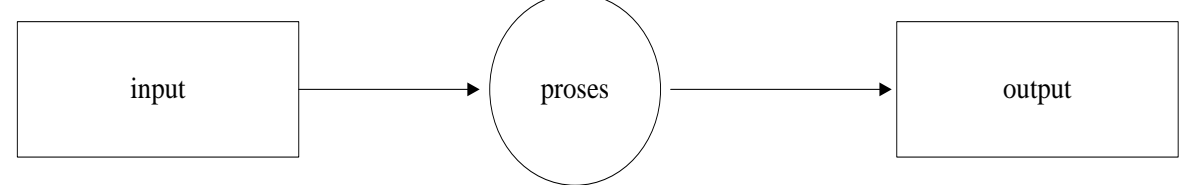

\section{Gambar 1 Siklus Pengolahan Data}


Pengertian Aplikasi Febrian (2007:35), "Aplikasi adalah program siap pakai atau program yang direka untuk melaksanakan suatu fungsi bagi pengguna atau aplikasi yang lain".

PHP (Personal Home Page ) PHP dahulunya merupakan proyek yang digunakan untuk membuat home page pribadi. Versi pertama ini berupa kumpulan script PERL. Untuk versi keduanya, Rasmus menulis ulang script-script PERL tersebut menggunakan bahasa C, kemudian menambahkan fasilitas untuk Form HTML dan koneksi MySQL. Adapun PHP didapat dari singkatan dari singkatan Personal Home Page. Setelah mengalami perkembangan oleh suatu kelompok open source (termasuk Rasmus) maka mulai versi 3 nya, PHP telah menampakan keunggulangnya sebagai salah satu bahasa server scripting yang handal. Memulai perkembangan yang pesat ini banyak fasilitas yang ditambahkan dan oleh kelompok ini PHP disebut sebagai "PHP : Hypertext Processor" Sintaks yang digunakan berasal dari bahasa $\mathrm{C}$ maupun java.

PHP merupakan bahasa script yang digunakan untuk membuat halaman web yang dinamis berarti halaman yang akan ditampilkan dibuat saat halaman itu diminta oleh client. Mekanisme ini menyebabkan informasi yang diterima client selalu yang terbaru.

Database (Basis Data) Database merupakan suatu kumpulan data atau arsip yang saling berhubungan yang di simpan secara program aplikasi optimal tanpa mengalami ketergantungan pada program yang akan menggunakan proses penambahan, pengambilan dan modifikasi data dapat dilakukan dengan mudah dan terkontrol.

Dengan demikian, basisdata (database), yaitu kumpulan dari data yang saling berbungan satu dengan yang lainnya, tersimpan di perangkat keras komputer dan digunakan perangkat lunak untuk memanipulasinya.

Sistem basis data adalah sekumpulan subsistem yang terdiri atas basis data dengan para pemakai yang menggunakan basis data secara bersama-sama personal yang merancang dan mengelola basis data, serta sistem komputer untuk mendukungnya.

Data adalah bahan keterangan tentang kejadian-kejadian nyata atau fakta-fakta yang merumuskan dalam sekelompok tertentu tentang yang tidak acak untuk menunjukkan jumlah, tindakan atau hal.

Pendampingan dan pelatihan di lakukan kepada para kolektor dan admin serta bendahara Koperasi Perhimpunan Simpan Pinjam Mandiri Paroki Padrepio Medan.

Tabel 1 Daftar Peserta Pelatihan

\begin{tabular}{cll}
\hline Peserta & $\begin{array}{l}\text { Ruang Lingkup } \\
\text { pendampingan }\end{array}$ & Pendamping dan Pelatih \\
\hline Para Kolektor & Ranah dan tugas kolektor & $\begin{array}{l}\text { Megaria Purba,Marice Saragih dan } \\
\text { Veronika Saragih }\end{array}$ \\
\hline Bendahara & Ranah dan tugas bendahara & $\begin{array}{l}\text { Megaria Purba, Marice Saragih } \\
\text { dan Veronika Saragih }\end{array}$ \\
\hline Admin & Ranah dan tugas admin & $\begin{array}{l}\text { Megaria Purba, Marice Saragih dan } \\
\text { Veronika Saragih }\end{array}$ \\
\hline
\end{tabular}

\section{Metode Penelitian}

Pelatihan pengemasa roti ubi talas dan pengoperasian aplikasi pemasaran online dilaksanakan dengan metode sebagai berikut : 
1. Pemberitahuan lokasi tempat petemuan dan waktu yang sudah disepakati. Pada tahap Ini kami sebelumnya akan menghubungi ketua Koperasi Perhimpunan Simpan Pinjam Mandiri Padrepio untuk menentukan pertemuan untuk menetukan musawarah sesuai dengan jadwal dan tempat agar kegiatan dapat terlaksana dengan baik.

2. Memberikan ceramah dan motivasi serta memperkenalkan tori, spesiikasi perangkat lunak,spesifikasi perangkat keras dan istilah yang digunakan dalam penerapan Aplikasi Koperasi simpan Pinjam Mandiri Paroki Padrepio sesuai dengan modul yang sudah dibagikan. .

3. Memberikan pelatihan dan pendampingan mitra dalam menerapkan aplikasi mulai membuka halaman web, login,pengimputan, penampilan hasil, database serta penguasaan ruang lingkup sesuai jabatan sebagai kolektor dan admin serta bendahara.

4. Memberikan pelatihan dan pendampingan dalam pemeliharaan sofware dan hardware yang digunakan dalam penerapan aplikasi.

\section{HASIL DAN PEMBAHASAN}

Hasil pendampingan dan pelatihan serta penagungjawab pada pengabdian penerapan Aplikasi Perhimpunan Simpan Pinjam Mandiri Paroki Padrepio dapat di tampilkan pada tabel 2.

Tabel 2 Hasil Pelatihan Mitra

\begin{tabular}{lcccl}
\hline Keterampilan yang di latih & Peserta & Satuan & Dokumen & $\begin{array}{c}\text { Penanggung } \\
\text { Jawab }\end{array}$ \\
\hline $\begin{array}{l}\text { Musawarah penetuan lokasi } \\
\text { dan jadwal pelatihan }\end{array}$ & 4 & orang & Lampiran 1 & $\begin{array}{l}\text { Megaria Purba,Marice } \\
\text { Saragih dan Veronika } \\
\text { Saragih }\end{array}$ \\
\hline $\begin{array}{l}\text { Pelatihan Pengenalan fitur } \\
\text { dan menjalankan aplikasi } \\
\text { sesuai modul }\end{array}$ & 10 & orang & Lampiran 2 & $\begin{array}{l}\text { Megaria Purba,Marice } \\
\text { Saragih dan Veronika } \\
\text { Saragih }\end{array}$ \\
\hline $\begin{array}{l}\text { Pelatihan pengimputan dan } \\
\text { tampilan hasil database } \\
\text { sesuai modul }\end{array}$ & 10 & orang & Lampiran 3 & $\begin{array}{l}\text { Megaria Purba,Marice } \\
\text { Saragih dan Veronika } \\
\text { Saragih }\end{array}$ \\
\hline $\begin{array}{l}\text { Pelatihan pendampingan } \\
\text { pemeliharaan sofware dan } \\
\text { hardware sesuai modul }\end{array}$ & 10 & orang & Lampiran 4 & $\begin{array}{l}\text { Megaria Purba,Marice } \\
\text { Saragih dan Veronika } \\
\text { Saragih }\end{array}$ \\
\hline
\end{tabular}
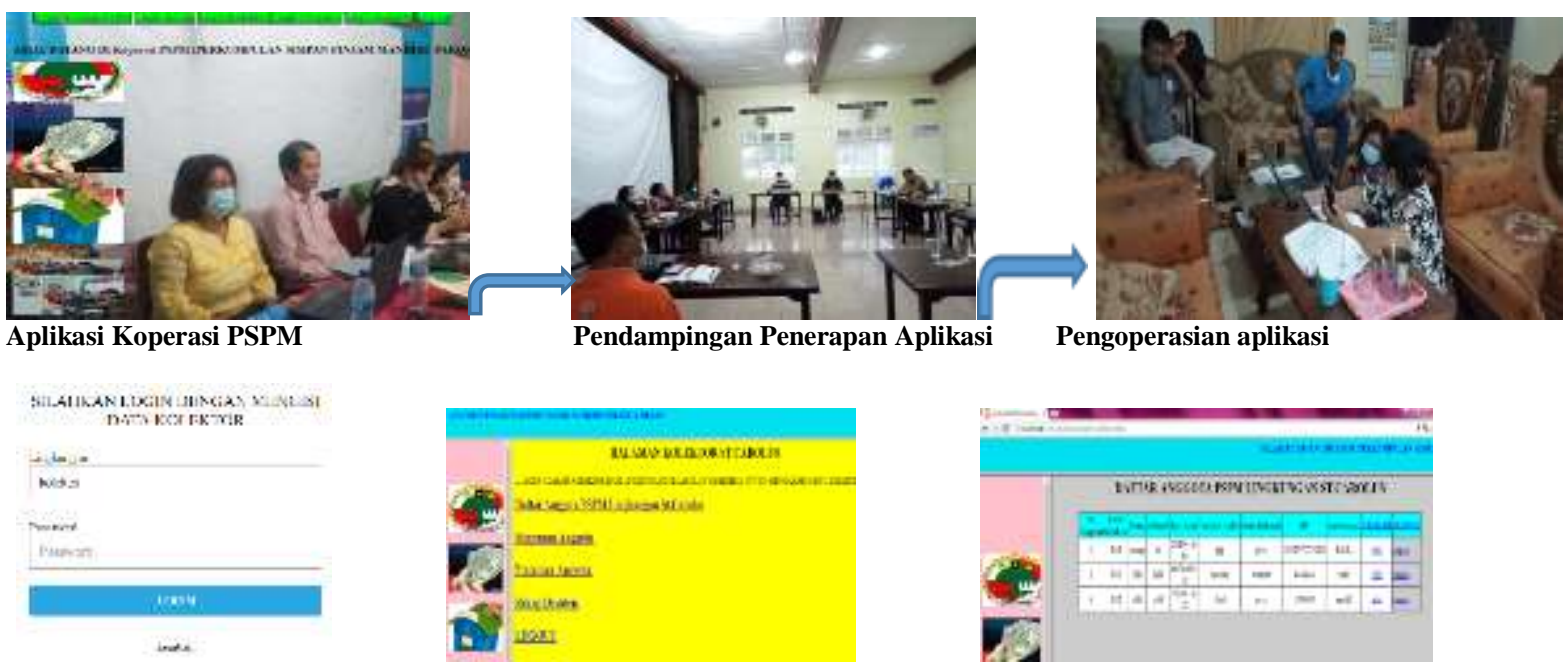
https://jurnal.amikwidyaloka.ac.id/index.php/awl

jurnal@amikwidyaloka.ac.id / editor.jurnalwidya@gmail.com

\section{KESIMPULAN}

Pelatihan yang dilakukan kepada mitra Koperasi Perhimpunan Simpan Pinjam Mandiri Paroki Padrepio Medan mampu menggunakan aplikasi yang diterapkan sehingga transaksi dapat dilakukan dengan cepat dan akurat.

\section{REFERENSI}

[1] Megaria Purba, 2020, Aplikasi Koperasi Perhimpunan Simpan Pinjam Mandiri (Pspm) Paroki Padrepio ,(vols 4),Medan,Skylandsea.

[2] Yahfizham, 2019,Dasar Komputer, Jl. Sosro No. 16-A Medan 20224, Perdana Mulya Sarana

[3] Riyanto. 2015. XAMPP. Yogyakarta: Gava Media.

[4] Benni Triyono, Sri Purwanti, Verdi Yasin (2017) "Rekayasa Perangkat Lunak Sistem Informasi Pengiriman Dan Penerimaan Surat Atau Paket Berbasis Web", Journal of Information System, Applied, Management, Accounting and Research, e-ISSN: 2598-8719. p-ISSN: 2598-8700.Vol.1 No.1 (30 Desember 2017) p46-53 http://journal.stmikjayakarta.ac.id/index.php/iisamar/article/view/12

[5] Julinda Maya Paramudita, Verdi Yasin (2019) "Perancangan Aplikasi Sistem Penyewaan Alat Berat (studi kasus: PT. Jaya Alam Sarana Jakarta) “, Journal of Information System, Applied, Management, Accounting and Research, e-ISSN: 2598-8719. p-ISSN: 2598-8700.Vol.3 No.1 (20 Februari 2019) p2329 http://journal.stmikjayakarta.ac.id/index.php/iisamar/article/view/73

[6] Muryan Awaludin, Verdi Yasin (2020) "Application Of Oriented Fast And Rotated Brief (Orb) And Bruteforce Hamming In Library Opencv For Classification Of Plants", Journal of Information System, Applied, Management, Accounting and Research, e-ISSN: 2598-8719. p-ISSN: 2598-8700.Vol.4 No.3 (14 Agustus 2020) p51-59 http://iournal.stmikjayakarta.ac.id/index.php/iisamar/article/view/247

[7] Ifan Junaedi, Dimas Abdillah, Verdi Yasin (2020) "Analisis Perancangan Dan Pembangunan Aplikasi Business Intelligence Penerimaan Negara Bukan Pajak Kementerian Keuangan RI”, Journal of Information System, Applied, Management, Accounting and Research, e-ISSN: 2598-8719. p-ISSN: 2598-8700.Vol.4 No.3 (14 Agustus 2020) p88-101 http://iournal.stmikjayakarta.ac.id/index.php/iisamar/article/view/249

[8] Verdi Yasin (2012) 'Rekayasa Perangkat Lunak Berorientasi Objek”, Penerbit: Mitra Wacana Media, JakartaIndonesia.

[9] Anis Rohmadi, Verdi Yasin (2020) “Desain Dan Penerapan Website Tata Kelola Percetakan Pada CV Apicdesign Kreasindo Jakarta Dengan Metode Prototyping", Journal of Information System, Informatics and Computing. E-ISSN: 2597-3673 (Online), P-ISSN: 2579-5201 (Print) Vol. 4 No.1, June 22, 2020. Pp.70-85 http://journal.stmikjayakarta.ac.id/index.php/jisicom/article/view/210

[10] Septian Cahyadi, Verdi Yasin, Mohammad Narji, Anton Zulkarnain Sianipar (2020) "Perancangan Sistem Informasi Pengiriman Dan Penerimaan Soal Ujian Berbasis Web ( Studi Kasus: Fakultas Komputer Universitas Bung Karno)", Journal of Information System, Informatics and Computing. E-ISSN: $2597-$ 3673 (Online), P-ISSN: 2579-5201 (Print) Vol. 4 No.1, June 22, 2020. Pp.1-16 http://journal.stmikjayakarta.ac.id/index.php/jisicom/article/view/199

[11] Ifan Junaedi, Ndaru Nuswantari, Verdi Yasin (2019) “Perancangan Dan Implementasi Algoritma C4.5 Untuk Data Mining Analisis Tingkat Risiko Kematian Neonatum Pada Bayi", Journal of Information System, Informatics and Computing. E-ISSN: 2597-3673 (Online), P-ISSN: 2579-5201 (Print) Vol. 3 No.1, February 13, 2019. Pp.29-44. http://journal.stmikjayakarta.ac.id/index.php/jisicom/article/view/203

[12] Verdi Yasin, Anindra Ramdhan Nugraha, Muhammad Zarlis, Ifan Junaedi (2018) "Smart System Of Fast Internet Access Development Using Backbone Network Method", Journal of Information System, Informatics and Computing. E-ISSN: 2597-3673 (Online), P-ISSN: 2579-5201 (Print) Vol. 2 No. 2, December 31, 2018. Pp.26-34. http://journal.stmikjayakarta.ac.id/index.php/jisicom/article/view/198

[13] Ito Riris Immasari, Verdi Yasin (2019) “Penggunaan Metode Analytic Hierarchy Process Untuk Menganalisis 
Faktor-Faktor Yang Mempengaruhi Pemilihan Calon Legislatif Di Dprd li Kota Tangerang", Journal of Information System, Informatics and Computing. E-ISSN: 2597-3673 (Online), P-ISSN: 2579-5201 (Print) Vol. 3 No. 2, December 10, 2019. Pp.53-58.

http://journal.stmikjayakarta.ac.id/index.php/jisicom/article/view/139

[14] Verdi Yasin, Muhammad Zarlis, Tulus, Erna Budhiarti Nababan, Poltak Sihombing (2019) "Rancangan Miniatur Otomatisasi Bel Listrik Pada Gerbang Pintu Menggunakan Microkontroler Atmega8535", Journal of Information System, Informatics and Computing. E-ISSN: 2597-3673 (Online), P-ISSN: 2579-5201 (Print) Vol. 3 No. 1, February 13, 2019. Pp.13-20 http://journal.stmikjayakarta.ac.id/index.php/jisicom/article/view/68

[15] Anggeri S. Nurjaman, Verdi Yasin (2020) "Konsep Desain Aplikasi Sistem Manajemen Kepegawaian Berbasis Web Pada PT. Bintang Komunikasi Utama ”, Journal of Information System, Informatics and Computing. E-ISSN: 2597-3673 (Online), P-ISSN: 2579-5201 (Print) Vol. 4 No. 2, December 28, 2020. Pp.143-174 http://journal.stmikjayakarta.ac.id/index.php/jisicom/article/view/363

[16] Verdi Yasin, Azhar Ahmad Riza, Rumadi Hartawan (2017) "Pengembangan Aplikasi Pemulihan Layanan Bencana Sistem Informasi Peneriman Negara Bukan Pajak Online Di Lingkungan Kementerian Keuangan Republik Indonesia”, Journal of Information System, Informatics and Computing. EISSN: 2597-3673 (Online), P-ISSN: 2579-5201 (Print) Vol. 1 No. 1, September 20, 2017. Pp.33-56. http://journal.stmikjayakarta.ac.id/index.php/jisicom/article/view/4

[17] Verdi Yasin (2021) "Penerapan sistem kegiatan belajar dan mengajar dalam instrumen Sertifikasi Dosen Profesional menggunakan metode SMART”, Tridharmadimas: Jurnal Pengabdian Kepada Masyarakat Jayakarta,E-ISSN: 2798-8295 (Online), P-ISSN: 2798-8554 (Print) page: 37-55 DOI: 10.52362/tridharmadimas.v1i1.501 URL: http://journal.stmikjayakarta.ac.id/index.php/tridharmadimas/article/view/501 